\title{
Appendix 1: Corporate history of Rosneft
}

1991

The Ministry of the Oil and Gas Industry of the USSR was abolished, and Rosneftegaz was formed based on it (Ppnf.ru 2011).

Alexander Putilov, the former Head of Uraineftegaz, was appointed President of Rosneft (Lenta.ru 2012; Osipov 2013).

The state enterprise Rosneft was founded, based on assets previously held by Rosneftegaz and Rosnefteprodukt (Osipov 2013; Rosneft 20171).

Rosneft lost valuable assets to the newly established SIDANCO, Eastern Oil Company and ONACO.

Purneftegaz, the key subsidiary of Rosneft, was transferred to SIDANCO.

Rosneft lost valuable assets to the newly established TNK and Sibneft.

Open joint stock company (OJSC) Rosneft was established in accordance with Russian Government Decree 971 (Rosneft 20171).

Purneftegaz was transferred back to Rosneft.

The production-sharing agreement (PSA) for the Sakhalin-1 project came into effect. Its shareholders included Exxon as project operator (30\%) and SODECO (30\%), with the remaining $40 \%$ being divided between Sakhalinmorneftegaz-Shelf (a subsidiary of SMNG) and Rosneft.

SIDANCO filed a lawsuit demanding the return of Purneftegaz.

The court recognized the validity of SIDANCO's claim concerning Purneftegaz, but Vladimir Potanin decided to return it to Rosneft.

Yuri Bespalov, the former Minister of Industry (1996-97), was appointed President of Rosneft (Lenta.ru 2012).

The government developed the first plans to privatize Rosneft.

The government decided to sell $75 \%+1$ share of Rosneft. The auction was first scheduled for May, but it was then postponed until autumn.

The financial crisis hit; the privatization auction was postponed indefinitely.

Sergei Bogdanchikov, the former General Director of Rosneft's subsidiary Sakhalinmorneftegaz, was appointed President of Rosneft (Lenta.ru 2012; Osipov 2013).

A cost-cutting programme was launched (Sputniknews 2005).

For the first time after the financial crisis, Rosneft reported a profit (Lenta.ru 2012).

Rosneft started rebuilding Chechnya's oil industry (Lenta.ru 2012).

Rosneft received permission from the Russian Anti-Monopoly Ministry to increase its stake in subsidiaries to $75 \%$. 
An agreement was signed with Gazprom on joint Arctic offshore development, and the Sevmorneftegaz joint venture was established on a 50:50 basis (Sputniknews 2005).

2001 Rosneft became the first Russian oil company after the 1998 crisis to issue Eurobonds to European and American investors (Sputniknews 2005).

2001 Rosneft and Stroytransgaz were declared the winners of the first international tender for exploration of hydrocarbons in Algeria.

2001 Rosneft sold half of its share in Sakhalin-1 to the Indian Oil and Natural Gas Corporation (ONGC).

2001 Rosneft and Sinopec began working on a 50:50 basis on the Adaisk zone in Kazakhstan.

2002 Rosneft obtained a licence to develop the Kaygansko-Vasyukansky block as part of the Sakhalin-5 project (Rosneft 20171).

2003 Rosneft bought Severnaya Neft (Lenta.ru 2012).

2003 Rosneft took under its control the Vankor field in Eastern Siberia.

2003 Rosneft bought Selkupneftegaz and Pur Oil Company (Novatek 2005).

2003 Rosneft bought a 50\% stake in the Polar Lights joint venture with ConocoPhillips.

2003 Rosneft received a licence to develop the Veninsky block, part of the Sakhalin-3 project (Rosneft 20171).

2003 Rosneft received an exploration licence for the West Kamchatka shelf.

2003 In February, at a meeting between President Vladimir Putin and representatives of the Russian Union of Industrialists and Entrepreneurs, the Head of YUKOS, Mikhail Khodorkovskiy, confronted the Head of Rosneft, Sergei Bogdanchikov (Lenta.ru 2012).

2003 First, Platon Lebedev and then Mikhail Khodorkovskiy were arrested, and the YUKOS case began.

2004 Vladimir Putin's close ally Igor Sechin was appointed chairman of the board of directors of Rosneft (Osipov 2013; Rosneft 20171).

2004 Rosneft signed a MoU with KNOC concerning the joint development of the West Kamchatka shelf (Rigzone 2004).

2004 In September, Vladimir Putin approved a government proposal to fully incorporate Rosneft into Gazprom in exchange for $10.74 \%$ in the gas monopoly that was held by its subsidiaries.

2004 The government froze the shares of YUKOS subsidiary Yuganskneftegaz, claiming that shares would soon be sold to cover tax debts (Lenta.ru 2012).

2004 In December, the Yuganskneftegaz auction was held; the company was bought by Baikal Finance Group.

2004 Rosneft acquired Baikal Finance Group (NGRF 2005; Osipov 2013).

2005 Chinese banks lent Rosneft USD 6 billion to be repaid in the form of oil exports to China.

2005 Oil production started in the Sakhalin-1 project (Sputniknews 2005).

2005 Rosneft signed an agreement with the Chinese company Sinopec to conduct geological exploration and prospecting within Veninsky block of Sakhalin-3 (China Daily 2007).

The Gazprom-Rosneft merger was disbanded (Wikipedia 2018). 

TNK-BP (Reuters 2007). Rosneft sold its stake in Sevmorneftegaz to Gazprom.

A PSA and an agreement on joint activities were signed in Astana for the Kurmangazy block to be developed by Rosneft and Kazmunaigaz in Kazakhstan. Rosneft nominated independent members to its board of directors. Rosneft made an initial public offering (IPO) on the London Stock Exchange and the Russian Trading System (RTS), selling 14.8\% of its shares (Rosneft 2017). Rosneft acquired the debts of YUKOS, becoming its second-biggest debtor after the Russian tax authorities. Sinopec bought Udmurtneft, acting in the interests of Rosneft. established Vostok Energy.

Rosneft decided to raise a loan of up to USD 13 billion and provide a guarantee for Rosneft-Development to raise up to USD 9 billion funds in debt to acquire the oil assets of YUKOS (NGFR 2005). Rosneft bought YUKOS's oil assets during the bankruptcy auctions of the latter (Osipov 2013). Rosneft was included in the list of strategic enterprises.

2007 Rosneft (49\%) and CNPC (51\%) established the PetroChina-Rosneft Orient Petrochemical (Tianjin) Company to build a refinery in China. Igor Sechin was appointed Deputy Prime Minister in charge of the energy sector.

2008 President Dmitriy Medvedev signed the federal law on 'Introducing Amendments to the Federal Law on the Continental Shelf', under which only Gazprom and Rosneft were given access to offshore fields.

Rosnedra refused to extend the West Kamchatka offshore exploration licence of Rosneft and its Korean partners.

Rosneft, LUKOIL, Gazprom Neft, TNK-BP and Surgutneftegas established the National Oil Consortium to develop Junin-6 block in Venezuela.

2009 Rosneft launched commercial production at Vankor (Rosneft 20171).

2009 Chinese banks lent Rosneft USD 15 billion to be repaid by oil exports to China (Reuters 2009).

2010 Rosneft acquired stakes in four refineries in Germany from Petróleos de Venezuela (PDVSA) (Rosneft 20171).

2010 Sergei Bogdanchikov was fired from Rosneft while he was on a business trip. Eduard Khudainatov, Head of Severneftegazprom, replaced Bogdanchikov (Lenta.ru 2012; Osipov 2013). transparency. Navalny tried to find out the details of the contract between Rosneft and CNPC (Osipov 2013). 
Rosneft invited Chevron to participate in its Black Sea ventures. Chevron withdrew from the joint Black Sea project with Rosneft. President Medvedev announced that all vice premiers and ministers of the Russian government must withdraw from the boards of directors of state-owned companies. Igor Sechin resigned from the board of directors of Rosneft and was replaced by the Vice President of the Russian Academy of Sciences, Alexander Nekipelov (Lenta.ru 2012).

A strategic alliance between Rosneft and BP was announced but it was soon torpedoed by the Russian shareholders of TNK-BP, that is, the AAR consortium (Rosneft 2011).

Rosneft formed a strategic partnership with ExxonMobil, centred on the joint development of Russian offshore Arctic oil and oil in the Mexican Gulf and Canada (Lenta.ru 2012).

The Kazakh Ministry of Oil and Gas terminated the Adaisk block PSA at the request of Rosneft and Sinopec.

In March 2012, Rosneft acquired 35.3\% of Taas-Yuryakh Neftegazodobycha from Sberbank and also increased its stake from $70.78 \%$ to $99.87 \%$ in Vostsibneftegaz (Rosneft 2012a).

Rosneft signed an agreement on strategic cooperation with Itera (Rosneft 2012b).

Igor Sechin became CEO of Rosneft (Osipov 2013; Rosneft 20171).

Rosneft reached a binding agreement to take over TNK-BP. The deal was finalized in March 2013 (Katona 2016; Osipov 2013; Rosneft 20171).

Rosneft and ExxonMobil signed an agreement to cooperate on tight oil reserves at the Bazhenov and Achimov formations in Western Siberia (Rosneft 20171).

Rosneft signed an agreement with Statoil (now Equinor) to establish a joint venture to work in the Barents Sea and the Sea of Okhotsk (Rosneft 20171).

Rosneft and ENI formed a joint venture to develop licence areas in the Barents and Black Seas (Rosneft 20171).

Rosneft and its international partners signed joint declarations on sustainable Arctic offshore developments.

Rosneft signed a major deal on gas supplies with Inter RAO.

Rosneft and Itera Group established a joint venture based on the assets of NGK Itera (Rosneft 2012c).

RN Cardium Oil bought a 30\% share in the Cardium project in the province of Alberta from ExxonMobil.

Rosneft, Transneft and CNPC resolved their conflict and agreed upon new delivery terms with the Russian companies providing a discount of USD 1.5 per barrel to CNPC.

Rosneft closed the deal on the acquisition of TNK-BP (Rosneft 20171).

Rosneft reached an agreement to buy several petroleum assets of ALROSA (Rosneft 2013g).

Rosneft reached an agreement with Enel to buy 40\% in Arctic Russia B.V. (Rosneft 2013a).

Rosneft and Novatek reached an agreement on an asset swap (Rosneft 2013b).

The Federal Anti-Monopoly Service allowed RN-East Siberia to purchase the remaining $64.67 \%$ of Taas-Yuryakh Neftegazodobycha (Rosneft 2013c). 
Rosneft and ExxonMobil expanded their strategic cooperation by including seven additional licensing plots covering an area of 600000 square kilometres in the Chukchi, Laptev and Kara seas (Rosneft 2013d).

2013 Rosneft and CNPC signed an export contract to deliver 360 million metric tonnes of crude over 25 years, worth some USD 270 billion. In addition, Rosneft and Sinopec signed a contract worth USD 85 billion under which Rosneft would supply 100 million metric tonnes of crude over ten years (Reuters 2013)

2013 The dividend was increased to RUB 85 billion, and RUB 2.7 trillion was transferred to the budget of the Russian Federation (Rosneft 20171).

2013 Rosneft, Gazprombank, Sovkomflot and DSME signed a MoU on cooperation for creating a shipbuilding and industrial cluster in Primorsky Kray. Rosneft was officially charged with the construction of an oil refinery in Chechnya. Rosneft became the third-largest gas producer in Russia after Gazprom and Novatek. Rosneft and ExxonMobil made plans to build an LNG plant in the Far East of Russia. Rosneft and Novatek successfully lobbied for changes in gas exports: a law granting export rights to certain LNG projects came into force, essentially ending Gazprom's monopoly. Rosneft (40\%) and CVP, a subsidiary of PDVSA, signed an agreement establishing Petrovictoria S.A. to develop Carabobo 2.

2013 Neftegaz America Shelf LP, a subsidiary of Rosneft, bought a 30\% share in 20 of ExxonMobil's deep-water blocks in the American part of the Mexican Gulf (Rosneft 2013e). Rosneft and Statoil (now Equinor) successfully participated in the twenty-second licensing round held by the government of Norway. Rosneft obtained important gas assets in Vietnam through its acquisition of TNK-BP. Rosneft bought a stake in the Saras refinery in Italy (Rosneft 2013f). Rosneft together with ExxonMobil discovered a large oil and gas field in the Kara Sea and called it Pobeda (Victory) (Rosneft 20171).

Rosneft strengthened its foothold in Germany by acquiring Total's $16.67 \%$ stake in the Schwedt refinery (Katona 2016).

Rosneft increased its stake in the Venezuelan National Oil Consortium to 80\% (Rosneft 2014e). Rosneft and PDVSA signed an agreement on cooperation to start production in the Rio Caribe and Mejillones blocks in Venezuela (Processing 2014).

Rosneft and PDVSA signed their first long-term contract for deliveries of oil and petroleum products to Russia from Venezuela.

Rosneft bought $100 \%$ of the Orenburg Drilling Company from VTB Leasing (Rosneft 2014a). US sanctions were introduced against Rosneft and against Igor Sechin personally.

17 Rosneft subsidiaries were placed under US sanctions, and ExxonMobil withdrew from the joint Kara Sea exploration drilling project (Katona 2016).

Rosneft bought drilling and well-repair assets in Russia and Venezuela from Weatherford International.

Rosneft and Cuban CUPET signed a Memorandum of Cooperation to implement projects in Cuba (Rosneft 2014b). 
Rosneft began to increase the share in the Solimoes project in Brazil, which it had inherited from TNK-BP (Rosneft 2014c).

2014 Rosneft acquired the Bishkek Oil Company in Kyrgyzstan (Rosneft 2014d).

2015 Rosneft commenced oil production at the Arkutun-Dagi field using Berkut, the world's largest drilling platform (Rosneft 20171).

2015 Rosneft acquired the SANORS holding company (Novokuybyshevsk Petrochemical Company) (Rosneft 20171).

2015 Rosneft bought the Russian subsidiary of Trican Well Service (Rosneft 2015d).

2015 The joint venture between Rosneft and BP to exploit the Domanic formation in the Orenburg region halted its activities because of the sanctions (Industryruss 2015).

2015 Moody's downgraded Rosneft's rating from Baa2 to Baa3, and S\&P downgraded its long-term credit rating of Rosneft's foreign currency debt from BBB- to BB+, with a 'negative' outlook.

2015 Rosneft closed a deal for the sale of its 50\% in the joint venture Polar Lights with ConocoPhllips (Rosneft 2015a).

2015 Rosneft and BP signed a deal to cooperate within the framework of Taas-Yuryakh Neftegazodobycha (BP bought 20\%) (Rosneft 2015b).

2015 Rosneft and ExxonMobil were announced the winners of three blocks in Mozambique, with ExxonMobil as the project operator.

2015 Rosneft and Sinopec signed an agreement on the joint development of the Russkoye and Yurubcheno-Tokhomskoye fields (Rosneft 2015c).

2016 Rosneft finalized a deal to sell $19.5 \%$ of its stock to Glencore and the Qatari sovereign wealth fund (Golubkova et al. 2016).

2016 Rosneft overtook Gazprom in terms of its capitalization in RTS.

2016 Rosneft bought the Bashneft oil company from the state for RUB 330 billion.

2016 Rosneft bought the Targin service company from AFK Sistema (Rosneft 2016d).

2016 Rosneft (51\%) and BP (49\%) signed an agreement on the establishment of the Yermak Neftegaz joint venture (Rosneft 2016a).

2016 Rosneft and ExxonMobil returned their licences for the blocks in the Gulf of Mexico.

2016 Rosneft dissolved its Ruhr Oel partnership with BP in Germany (Rosneft 2016b).

2016 Rosneft sold 49.9\% of Vankorneft to India's ONGC and a consortium of Indian investors, and $29.9 \%$ of Taas-Yuryakh Neftegazodobycha to the consortium (TASS 2016).

2016 In November, Alexei Ulyukayev, the Minister of Economic Development, was detained in the offices of Rosneft on charges of extortion and taking a bribe of USD 2 million for allowing the deal to sell shares of Bashneft to go through (BBC 2017; Caroll 2017; Revonenko 2017).

2016 Rosneft and Statoil (now Equinor) drilled two dry wells in the Sea of Okhotsk (OffshoreEnergy 2016b).

2016 Rosneft and the Indonesian company Pertamina signed preliminary agreements on the sale to the Indonesian company of stakes in the Russkoye field (up to 37.5\%) and in the northern part of Chaivo (up to 20\%) (OffshoreEnergy 2016a). 
PDVSA transferred to Rosneft $49.9 \%$ of Citgo, its American subsidiary that manages three refineries and oil pipelines in the United States, as a pledge under a pre-payment contract (Seekingalpha 2016).

2016 Rosneft was announced winner of the tender for the construction of the Tuban refining and petrochemical complex in Indonesia (HydrocarbonTechnology 2016).

2016 Rosneft invited ChemChina to a 40\% stake in its Eastern Petrochemical Company (Rosneft 2016c).

2016 Oil production at Vankor began to decline (Reuters 2016).

2017 Igor Sechin missed the court proceedings of the Ulyukaev case for the second time (Mironenko 2017; Reiter 2017; RFERL 2017c).

2017 Rosneft and Bashneft filed a claim with the Moscow Arbitration Court against AFK Sistema, the former owner of Bashneft, for RUB 106.6 billion. The court ultimately ruled that RUB 136.3 billion should be recovered from Sistema (BBC 2017; Polivanov 2017; Solodkov 2017).

2017 Rosneft decided not to build a refinery in Chechnya (RFERL 2017a).

2017 A conflict arose between Rosneft and the Chechen authorities over Chechenneftekhimprom (RFERL 2017b).

2017 QIA and Glencore agreed to sell the lion's share of their $14.16 \%$ stake to the largely unknown Chinese company, Clean Energy Finance Corporation (CEFC) (Daily Mail 2017).

2017 Rosneft acquired Kondaneft in its entirety (Rosneft 2017a).

2017 The European Court of Justice ruled that the EU sanctions against Rosneft were legitimate (Rosneft 2017b).

2017 Rosneft drilled a well in the Laptev Sea and announced the discovery of a field there (Rosneft 2017c).

2017 The joint venture between Rosneft and Statoil (now Equinor) began drilling the Domanic formation in Russia's Samara region (Rosneft 2017d).

2017 Rosneft sold 20\% in Verkhnechonskneftegaz to Beijing Gas and signed a provisional agreement to supply gas to China (Rosneft 2017e).

2017 Rosneft signed a MoU with BP concerning the sale and purchase of natural gas in Europe (Rosneft 2017f).

2017 Rosneft closed a deal to buy $30 \%$ in the licence for the Zohr field in the Mediterranean (Rosneft 2017g).

2017 Rosneft signed a wide-ranging strategic agreement with National Iranian Oil Company (NIOC) (Rosneft 2017h).

2017 Rosneft signed a cooperation agreement and several contracts with Kurdistan (Rosneft 2017i).

2017 Rosneft-Brazil started drilling the first exploration well in the Solimoes project (Rosneft 2017j).

2017 Rosneft sold its stake in the Saras refinery in Italy (Eurasiatx 2017).

2017 Russia became the largest oil supplier to China (Asia Dialogue 2017).

2017 Rosneft and CEFC Energy signed a strategic cooperation agreement during Xi Jinping's official visit to Russia (Rosneft 2017k).

2017 Rosneft in cooperation with partners bought EOL, owner of the Vadimar refinery in India (Reuters 2017). 

2019c).

2018 Moody's upgraded Rosneft's rating to investment level again, with a Baa3 rating and a 'stable' outlook (Rosneft 2019c).

2018 Bashneft, controlled by Rosneft, discovered an oilfield in Iraq (Rosneft 2019a).

2018 Ye Tsianmin, the board chairman of CEFC, was detained on charges of economic crimes, and CEFC's deal with Glencore and QIA collapsed (Reuters 2018).

\section{REFERENCES}

Asia Dialogue (2017), 'Russia not Saudi Arabia is China's main source of oil', accessed 4 March 2019 at http://theasiadialogue.com/2018/03/28/the-new-king-of-chinas -crude-oil-imports-russia-and-the-competition-for-market-share-in-china/.

BBC (2017), 'Rosneft vs AFK Sistema: Istoriya konflikta', accessed 21 September 2017 at http://www.bbc.co.uk/guides/zwhx8mn.

Caroll, O. (2017), 'Exotic locations, alleged bungs, secret recordings and a basket of sausages: Putin's friend and a no-show in court for Russia's landmark state oil bribery case', accessed 14 November 2017 at https://www.independent.co.uk/news/ world/europe/alexei-ulyukayev-bribery-trial-russian-economics-minister-rosneft -igor-sechin-extortion-vladimir-a8051926.html.

China Daily (2007), 'Sinopec, Rosneft deal on Sakhalin project', accessed 4 March 2019 at http://www.chinadaily.com.cn/business/2007-03/30/content_840389.htm.

DailyMail (2017), 'Glencore, Qatar finalize Rosneft deal', accessed 4 March 2019 at https://www.dailymail.co.uk/wires/afp/article-4986094/Glencore-Qatar-finalise -Rosneft-deal.html.

Eurasiatx (2017), 'Rosneft withdraws from Italian Saras', accessed 4 March 2019 at http://eurasiatx.com/rosneft-withdraws-italian-saras/.

Golubkova, K., D. Zhdannikov and S. Jewkes (2016), 'How Russia sold its oil jewel: Without saying who bought it', accessed 21 September 2017 at https://www.reuters .com/article/us-russia-rosneft-privatisation-insight/how-russia-sold-its-oil-jewel -without-saying-who-bought-it-idUSKBN1582OH.

Hydrocarbontechnology (2016), 'Rosneft and Pertamina to develop \$13bn Tuban oil refinery in Indonesia', accessed 4 March 2019 at https://www.hydrocarbons -technology.com/news/newsrosneft-pertamina-develop-13bn-tuban-oil-refinery -indonesia-4905914/.

Industryruss (2015), 'Rosneft signs agreements with BP', accessed 4 March 2019 at https://industryruss.wordpress.com/2014/05/27/rosneft-signs-agreements-with-bp/.

Katona, V. (2016), 'What you need to know about Rosneft', accessed 20 September 2017 at https://russia-direct.org/opinion/what-you-need-know-about-rosneft.

Lenta.ru (2012), 'Rosneft', accessed 19 September 2018 at https://lenta.ru/lib/ $14166182 /$.

Marchmonthnews (2010), 'Rosneft to build \$545m oil refinery in Chechnya', accessed 4 March 2019 at http://marchmontnews.com/Materials-Extraction/Volga/11210 -Rosneft-build-545m-oil-refinery-Chechnya.html. 
Mironenko, P. (2017), 'The Bell nashel zapisi peregovorov Ulyukaeva i Sechina', accessed 27 November 2017 at https://thebell.io/the-bell-nashel-zapisi-peregovorov -ulyukaeva-i-sechina-v-den-zaderzhaniya-ministra/.

NGFR (2005), 'Rosneft', accessed 21 September 2017 at http://www.ngfr.ru/library .html?rosneft.

Novatek (2005), 'Novatek and Rosneft enter cooperation agreement', accessed 4 March 2019 at http://www.novatek.ru/en/press/releases/archive/index.php?id_4= 260\&mode_4=all\&afrom_4=01.01.1990\&from_4=84.

OffshoreEnergy (2016a), 'Pertamina to buy stake in Rosneft's Chayvo field', accessed 4 March 2019 at https://www.offshoreenergytoday.com/pertamina-to-buy-stake-in -rosnefts-chayvo-field/.

OffshoreEnergy (2016b), 'Rosneft: COSL to drill two wells in Okhotsk Sea', accessed 4 March 2019 at https://www.offshoreenergytoday.com/rosneft-cosl-to-drill-two -wells-in-okhotsk-sea/.

Osipov, I. (2013), 'Put Rosnefti: Ot raspada Soyuza do pokupki TNK-BP', accessed 25 February 2017 at http://www.Forbes.ru/novosti-photogallery/236077-put-rosnefti-ot -raspada-soyuza-do-pokupki-tnk-bp?photo=1.

Polivanov, A. (2017), 'Rosneft protiv AFK Sistema - glavnaya istoriya sovremennogo rossiyskogo biznesa. I vot pochemu', accessed 21 September 2017 at https://meduza .io/slides/rosneft-protiv-afk-sistema-glavnaya-istoriya-sovremennogo-rossiyskogo -biznesa-i-vot-pochemu.

Ppnf.ru (2011), 'AO Rosneft', accessed 18 September 2018 at http://ppnf.ru/oao/ rosneft/.

Processing (2014), 'Rosneft, PDVSA sign collaboration agreements', accessed 4 March 2019 at https://www.processingmagazine.com/rosneft-pdvsa-sign-collaboration -agreements/.

Reiter, S. (2017), 'Pervyy dopros Ulyukaeva: Nigde i nikogda ya ne treboval u nego nikakuyu vzyatku', accessed 27 November 2017 at https://thebell.io/ulyukaev -pervye-pokazaniya/.

Reuters (2007), 'Rosneft, TNK-BP agree to share disputed oil stake', accessed 4 March 2019 at https://uk.reuters.com/article/rosneft-tnkbp-shares -idUKL2312292920070523.

Reuters (2009), 'China lends Russia \$25 billion to get 20 years of oil', accessed 4 March 2019 at https://uk.reuters.com/article/uk-russia-china-oil-sb/china-lends -russia-25-billion-to-get-20-years-of-oil-idUKTRE51G3S620090217.

Reuters (2013), 'Rosneft to double oil flows to China in $\$ 270$ billion deal', accessed 4 March 2019 at https://www.reuters.com/article/us-rosneft-china/rosneft-to-double -oil-flows-to-china-in-270-billion-deal-idUSBRE95K08820130621.

Reuters (2016), 'Russia's Rosneft says oil output at Vankor field to decline to $21 \mathrm{mln}$ T this year', accessed 4 March 2019 at https://af.reuters.com/article/ commoditiesNews/idAFR4N0ZC02O.

Reuters (2017), 'Rosneft seals first Asian refinery deal with Essar Oil purchase', accessed 4 March 2019 at https://www.reuters.com/article/us-india-essar-rosneft/ rosneft-seals-first-asian-refinery-deal-with-essar-oil-purchase-idUSKCN1B10PL.

Reuters (2018), 'China's CEFC chairman investigated for suspected economic crimes: Source', accessed 4 March 2019 at https://www.reuters.com/article/us-china-cefc -probe/chinas-cefc-chairman-investigated-for-suspected-economic-crimes-source -idUSKCN1GD3O9.

Revonenko, A. (2017), 'Sechin protiv sistemy. Istorija protivostoyaniya', accessed 21 September 2017 at https://openrussia.org/notes/710925/RFE/RL(2017). 
RFERL (2017a), 'Chechnya's Kadyrov, Rosneft again at odds', accessed 4 March 2019 at https://www.rferl.org/a/caucasus-report-chechnya-kadyrov-rosneft-sechin -dispute/28692549.html.

RFERL (2017b), 'Prospects for Chechnya's oil sector remain unclear', accessed 4 March 2019 at https://www.rferl.org/a/caucasus-report-chechnya-oil-sector -prospects-kadyrov/28221846.html.

RFERL (2017c), 'Russian court repeats summons after State Oil Company Chief Sechin skips hearing', accessed 14 November 2017 at https://www.rferl.org/a/ rosneft-sechin-court-summons-extortion-trial-ulyukayev/28850567.html.

Rigzone (2004), 'Rosneft and KNOC team up in Russian Far East', accessed 4 March 2019 at https://www.rigzone.com/news/oil_gas/a/16543/rosneft_and_knoc_team up_in_russian_far_east/.

Rosneft (2011), 'Rosneft and BP form global and Arctic strategic alliance', accessed 4 March 2019 at https://www.rosneft.com/press/releases/item/114519/.

Rosneft (2012a), 'Rosneft and Sberbank reach agreement in principle on Taas-Yuryakh project', accessed 4 March 2019 at https://www.rosneft.com/press/releases/item/ $114488 /$.

Rosneft (2012b), 'Rosneft and ITERA Group sign strategic cooperation agreement', accessed 4 March 2019 at https://www.rosneft.com/press/releases/item/114485/.

Rosneft (2012c), 'Rosneft and ITERA Group close deal to create joint venture to produce and sell gas', accessed 4 March 2019 at https://www.rosneft.com/press/ releases $/$ item $/ 114452 /$.

Rosneft (2013a), 'Rosneft acquires Enel stake in SeverEnergia', accessed 4 March 2019 at https://www.rosneft.com/press/releases/item/114329/.

Rosneft (2013b), 'Rosneft and Novatek agree assets swap', accessed 4 March 2019 at https://www.rosneft.com/press/releases/item/84244/.

Rosneft (2013c), 'Rosneft consolidates 100\% of Taas-Yuryakh Neftegazodobycha', accessed 4 March 2019 at https://www.rosneft.com/press/releases/item/24360/.

Rosneft (2013d), 'Rosneft and ExxonMobil expand strategic cooperation', accessed 4 March 2019 at https://www.rosneft.com/press/releases/item/11409/.

Rosneft (2013e), 'Rosneft subsidiary acquires interest in ExxonMobil Gulf of Mexico exploration blocks', accessed 4 March 2019 at https://www.rosneft.com/press/ releases/item/114405/.

Rosneft (2013f), 'Rosneft acquires minority stake in Saras S.p.A.', accessed 4 March 2019 at https:/www.rosneft.com/press/releases/item/114399/.

Rosneft (2013g), 'Rosneft acquires ALROSA oil and gas assets', accessed 4 March 2019 at https://www.rosneft.com/press/releases/item/23709/.

Rosneft (2014a), 'Rosneft acquires Orenburg Drilling Company', accessed 4 March 2019 at https://www.rosneft.com/press/releases/item/125322/.

Rosneft (2014b), 'Rosneft signed memorandum of cooperation with Cuba Petroleo', accessed 4 March 2019 at https://www.rosneft.com/press/releases/item/153292/.

Rosneft (2014c), 'Rosneft Brazil and HRT sign final agreements on the Solimoes Project', accessed 4 March 2019 at https://www.rosneft.com/press/releases/item/ $119118 /$.

Rosneft (2014d), 'Rosneft to acquire Bishkek Oil Company', accessed 4 March 2019 at https://www.rosneft.com/press/releases/item/95189/.

Rosneft (2014e), 'Rosneft increases its stake in the National Oil Consortium to $80 \%$ of shares', accessed 4 March 2019 at https://www.rosneft.com/press/releases/item/ $173609 /$. 
Rosneft (2015a), 'Rosneft divest its shares in LLC Polar Lights Company', accessed 4 March 2019 at https://www.rosneft.com/press/releases/item/179543/.

Rosneft (2015b), 'Rosneft and BP complete transaction to sell 20\% share of Taas-Yuryakh Neftegazodobycha to BP', accessed 4 March 2019 at https://www .rosneft.com/press/releases/item/178483/.

Rosneft (2015c), 'Rosneft and Sinopec signed a memorandum of understanding on cooperation in gas and petroleum chemicals projects in East Siberia', accessed 4 March 2019 at https://www.rosneft.com/press/releases/item/179545/.

Rosneft (2015d), 'Rosneft acquires a Russian oilfield service company from Trican Well Service Ltd', accessed 4 March 2019 at https://www.rosneft.com/press/ releases/item/174453/.

Rosneft (2016a), 'BP and Rosneft create joint venture to develop prospective resources in East and West Siberia', accessed 4 March 2019 at https://www.rosneft.com/press/ releases/item/182641/.

Rosneft (2016b), 'Rosneft and BP conclude dissolution of the refining joint venture Ruhr Oel GmbH in Germany', accessed 4 March 2019 at https://www.rosneft.com/ press/releases/item/185259/.

Rosneft (2016c), 'Rosneft and ChemChina signed an agreement setting out the framework for further implementation of the FEPCO project', accessed 4 March 2019 at https://www.rosneft.com/press/releases/item/183517/.

Rosneft (2016d), 'Rosneft acquires Targin Oilfield Services Company', accessed 4 March 2019 at https://www.rosneft.com/press/releases/item/185193/.

Rosneft (2017a), 'Rosneft acquires a strategic asset in the new production cluster in Khanty-Mansiysk Autonomous District', accessed 4 March 2019 at https://www .rosneft.com/press/releases/item/186209/.

Rosneft (2017b), 'Rosneft is disappointed by the decision of the EU Court of Justice concerning the estimation of legitimacy of the European sanctions', accessed 4 March 2019 at https://www.rosneft.com/press/releases/item/186035/.

Rosneft (2017c), 'Rosneft discovers hydrocarbon deposits on Eastern Arctic shelf', accessed 4 March 2019 at https:/www.rosneft.com/press/releases/item/186997/.

Rosneft (2017d), 'Rosneft and Statoil started pilot drilling as part of the development of Domanik sediments', accessed 4 March 2019 at https://www.rosneft.com/press/ releases/item/185549/.

Rosneft (2017e), 'Rosneft and Beijing Gas close the deal for sale and purchase of $20 \%$ shares in Verkhnechonskneftegaz', accessed 4 March 2019 at https://www.rosneft .com/press/releases/item/187075/.

Rosneft (2017f), 'BP and Rosneft agree strategic cooperation in gas business', accessed 4 March 2019 at https://www.rosneft.com/press/releases/item/186763/.

Rosneft (2017g), 'Rosneft closes the deal to acquire a 30\% stake in Zohr gas field', accessed 4 March 2019 at https://www.rosneft.com/press/releases/item/188045/.

Rosneft (2017h), 'Rosneft and National Iranian Oil Company sign oil and gas strategic cooperation agreement', accessed 4 March 2019 at https://www.rosneft.com/press/ releases/item/188381/.

Rosneft (2017i), 'Rosneft and the government of the Kurdish Autonomous Region of Iraq agree on cooperation at five production blocks', accessed 4 March 2019 at https://www.rosneft.com/press/releases/item/188125/.

Rosneft (2017j), 'Rosneft starts drilling the first exploration well at the Solimoes Project', accessed 4 March 2019 at https://www.rosneft.com/press/releases/item/ $185729 /$. 
Rosneft (2017k), 'Rosneft and CEFC deepen strategic cooperation', accessed 4 March 2019 at https://www.rosneft.com/press/releases/item/188599/.

Rosneft (20171), 'History of Rosneft', accessed 17 September 2017 at https://www .rosneft.com/about/History/.

Rosneft (2019a), 'Rosneft discovers new oil field in Iraq', accessed 8 February 2019 at https://www.rosneft.com/press/news/item/191233/.

Rosneft (2019b), 'Rosneft Deutschland successfully started direct marketing operations', accessed 8 February 2019 at https:/www.rosneft.com/press/news/item/ $191527 /$.

Rosneft (2019c), 'Ratings', accessed 4 March 2019 at https://www.rosneft.com/ Investors/Instrumenti_dlja_investora/Rejtingi/.

Seekingalpha (2016), 'Rosneft could take control of $49.9 \%$ of Citgo if PDVSA defaults', accessed 4 March 2019 at https://seekingalpha.com/news/3251534-rosneft -take-control-49_9-percent-citgo-pdvsa-defaults.

Solodkov, A. (2017), 'Protiv sistemy: Khronika protsessa po krupneyshemu isku Rosnefti', accessed 21 September 2017 at https://www.rbc.ru/business/07/12/2017/ 5952376e9a7947d0bb9e5308.

Sputniknews (2005), 'Timeline: Rosneft company history', accessed 19 September 2018 at https://sputniknews.com/russia/2005112442199615/.

TASS (2016), 'Indian companies invest $\$ 5$ bln in Vankorneft and TAAS-Yuryakh Neftegazodobycha - ONGC', accessed 4 March 2019 at http://tass.com/economy/ 905972.

Wikipedia (2018), 'Rosneft', accessed 19 September 2018 at https://en.wikipedia.org/ wiki/Rosneft. 